\title{
Developing And Implementing An Undergraduate Finance Capstone Course For Both Onground And Online Course Delivery
}

Linda S. Wiechowski, Walsh College, USA

\begin{abstract}
Capstone courses provide an opportunity to integrate several topics and to help prepare students for the real world. This paper examines the process of developing an undergraduate finance capstone course for both onground (face-to-face) and online course delivery. The process begins with the determination of the core competencies employers require of recent finance undergraduate students. Several of these core competencies are addressed in this paper, along with the challenges of assessing the competencies of team work and oral presentations skills online.
\end{abstract}

Keywords: Capstone courses; undergraduate finance curriculum; online course; teams; group project

\section{INTRODUCTION}

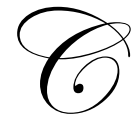

apstone courses are gaining in popularity and many colleges are adding these courses as a required final course for students in various disciplines (Smith, 1998). A capstone course is beneficial to students because it helps them to synthesize the material they have learned in several previous courses to construct an integrated whole (Heinemann, 1997). Capstone course could have one or more of the four main purposes: (1) integration (consolidating the several years of college education), (2) breadth (providing the students with a general education experience to enhance their specialized field of study), (3) application (provide the student with the opportunity for additional research in their specialization), (4) or transition (to aid the student in their life after their degree) (Levin, 1998).

This paper discusses the development and implementation of a finance capstone course required of all graduating BBA Finance students at Walsh College. The main purpose of the capstone course was to give the students the opportunity to bridge several courses together as well as to help them prepare for their careers. Since one of the goals is to prepare students for their career, the real world, it was imperative to determine what employers feel was important. A finance advisory board was formed at the school several years ago to guide the department in curriculum changes. This advisory board is composed of approximately ten local business professionals from the finance industry, including the areas of banking, insurance, and financial planning. While some of the board members have ties to Walsh (employers that recruit at Walsh, Walsh alumni, etc) many are unfamiliar with Walsh and were included in the group to provide an unbiased perspective.

In working with the finance advisory board, we were able to keep our finance curriculum relevant and up to date. However, some of the necessary skills are not specific to the finance specialization and have been taught outside the finance curriculum. While we may be able to assume that the students have the necessary technical skills (based on program assessment and student grades), they may not necessarily indicate the following core competencies that the college has determine to be the essential skills our graduates must possess: 


$$
\begin{array}{ll}
\text { 1. } & \text { presentation skills } \\
2 . & \text { writing skills } \\
3 . & \text { team work skills } \\
\text { 4. } & \text { technology skills } \\
\text { 5. } & \text { analytical skills }
\end{array}
$$

The decision was made to develop a capstone course that would give students some additional learning opportunities as well as provide practice with some of the above five competencies. In addition to weekly lectures and discussion activities, this capstone course also consists of several individual assignments and a group project. The individual assignments are used to provide students with additional technology and analytical skills practice. A group project is assigned that aids not only in the technology and analytical skills, but also includes components that help students with their presentation, writing and team work skills. This course was developed for both onground (face-to-face) and online delivery.

\section{FINANCE CAPSTONE COURSE DESCRIPTION}

The following is the course description as it appears in the Walsh College catalog:

This course explores applied financial modeling that integrates all previous financial coursework. The course content represents a blend of application and financial theory. Students will apply best practice estimating techniques and theory to calculate financial estimates of economic and business phenomena. The forecasts/estimates are calculated using Microsoft ${ }^{\circledR}$ EXCEL software which is generally available to most financial professionals. This course provides an opportunity for undergraduate finance students to develop practical financial modeling skills. Students will construct and utilize a variety of spreadsheets emphasizing specific, real-world problem solving. Financial modeling will be used for financial forecasting, sensitivity and simulation analysis, conducting financial statements analysis, debt and equity valuation, calculating the cost of capital, analyzing projects using discounted cash flow techniques, and capital budgeting. It is anticipated that students will be able to adapt these models to meet the needs of the workplace (Walsh College, 2010).

\section{COURSE LECTURES}

This course is designed for the BBA Finance student who is close to graduation. It is a three credit hour course that is taught in an onground format as well as an online format. The onground version of the course is taught in a computer lab with up to 24 students. Several of the weekly sessions consist of lectures and demonstrations on using Excel for topics such as: time value of money, capital budgeting, regression analysis and scenario analysis. The onground class sessions include a demonstration and in-class practice problems. The online class sessions include a video demonstration that was created using both Excel and Adobe ${ }^{\circledR}$ Captivate. The online class session includes practice problems as well. There is typically a weekly assignment that requires the use of Excel. This gives the students several opportunities to work on their analytic and technology skills. Both online and onground students receive instruction on the creation of professional quality PowerPoint slides.

\section{COURSE DELIVERABLES}

The students have several deliverables for the course: weekly Excel homework assignments, research project and presentation, midterm exam and final exam. Grading is based on the following table:

Figure 1: Assessment Table

\begin{tabular}{|l|c|}
\hline \multicolumn{1}{|c|}{ Assessment } & Points \\
\hline Exams (2 @ 100 pts each) & 200 \\
\hline Individual Assignments (6 @ 5 Points each) & 30 \\
\hline Research Project/Presentation & 80 \\
Industry Analysis Group Paper = 30 & \\
Company Analysis Individual Paper = 30 & \\
PowerPoint Presentation = 20 & 10 \\
\hline Research Paper Discussions and Critiques & $\mathbf{3 2 0}$ \\
\hline Total & \\
\hline
\end{tabular}




\section{Exams}

During the semester the students have two exams. The midterm and final exams consist of multiple choice questions and as well as several applied problems that require the student to create spreadsheets using Excel. Since this course is used for program outcomes assessment, the final exam also consists of a program post-test assessment component. The program post-test assessment data is compared with the program pre-test assessment data to determine the effectiveness of the program.

\section{Homework}

Technology proficiency is a core competency necessary for most finance professionals (French \& Coppage, 2004). The weekly Excel assignments allow the student the opportunity to learn new skills as well as practice the technology and analytical skills they already possess. The homework assignments also enable the student to work on their problem-solving skills. While most of the students have already been exposed to some of this material in other classes, they have not taken a class specifically on using Excel for financial analysis.

\section{Research Project}

The research project was designed to enable the students to work on all of five of the core competencies (presentation skills, writing skills, team work skills, technology skills and analytical skills). The project requires the students to form groups based on an industry of interest. The groups range in size between three and five students. Each student within the group selects a different company within the chosen industry to research. Each student writes a report about the company the selected and helps the group write a report about the industry. In class, the students work together on a short 30 minute presentation about their individually chosen companies. Each presentation must consist of a Microsoft ${ }^{\circledR}$ PowerPoint presentation that also encompasses the integration of Excel spreadsheets and graphs within the slides. The students are encouraged to meet with their group members to practice their presentations before presenting in class. The group is also responsible for holding a discussion after the presentation. A brief outline of the project for online delivery is as follows:

Figure 2: Research Project and Presentation Outline

Research Project and Presentation

A research project is required in the course. The research project consists of:

- Industry Analysis prepared as a group assignment

- Company Research Paper individually prepared by each member of the group

- Voiceover PowerPoint Presentation (VoPPT) individually prepared on the selected company within the Industry.

The research project as a whole should include the following elements:

- A Voiceover PowerPoint presentation (VoPPT) that introduces the project,

- Identifies data sources,

- Discusses the financial analysis,

- Makes conclusions from the data including recommendations;

- Also, the presentations should include a handout with the EXCEL spreadsheet.

The presentation will be delivered to the class using VoiceOver PowerPoint technology. Students will also be required to critique their classmates' presentations online in a Research Project discussion lab. 


\section{Student Presentations}

Online student presentations can be challenging. While there are several possible methods of having the students deliver synchronous presentations and discussions with software such as Wimba, we decided to have the presentations delivered asynchronously. Most Walsh students work full-time and have other time commitments that make it difficult to attend class online at a specific day and time, thus making synchronous class work difficult. Rather than eliminating the group project requirement for the online students, we have the students deliver the project asynchronously by creating voice-over PowerPoint presentations. This gives the online students the opportunity to become part of a virtual team. A team, as defined by Katzenberg and Smith, is "a small number of people with complementary skills who are committed to a common purpose, set of performance goals, and approach for which they hold themselves mutually accountable" (Katzenberg \& Smith, 2004, p. 5). A virtual team is a small group that works on high-level specific tasks either synchronously or asynchronously from different locations (Chidambaram \& Zigurs, 2001). Both the onground and online students have the opportunity to work in teams, the online students have the added experience of working in virtual teams. The online students also have the advantage of practicing and re-recording their voice-over PowerPoint slides to the point of perfection.

Onground and online presentations are followed up with a class discussion. The onground student teams lead a discussion on the topic in class. The online student teams host a discussion online in a discussion board. It is the responsibility of the team to lead the discussion for the week following their online presentation. The students are graded on their ability to lead the discussion. The other students are required to participate in the discussions and are graded as well. Each student is required to also critique the presentations of the group members from two other groups. Not only does this assure that students are paying attention to their classmates' presentations, it is also a learning experience for the student filling out the critique. Filling out the form will cause them to think about how they themselves present and how they can improve what they are doing as well as helping their classmates improve. According to Marquardt and Kearsley (1999), the requirement that students provide constructive and extensive feedback to each other should be built into all online courses. In this class, both online and onground students are required to critique their classmates. The students fill out the following critique form for each member of two assigned groups:

Figure 3: PowerPoint Critique Form

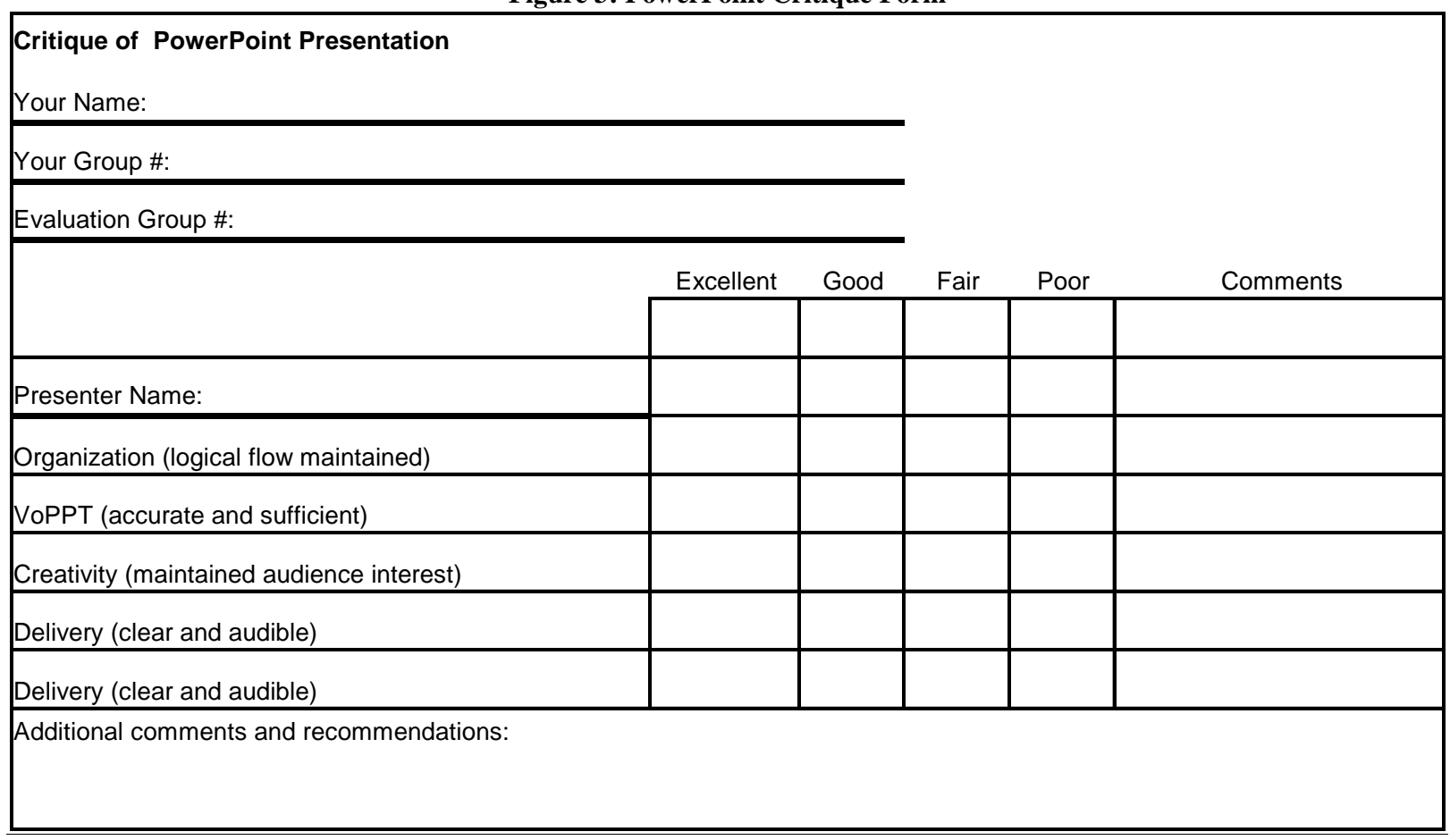


The instructor prepares a compilation of all of the PowerPoint critiques submitted by the classmates for each student. The student receives the scores as well as the comments, but the student does not know the name of the student that wrote the comments. The instructor comments are provided to the student as well. The goal is for the students to learn from each other, seeing what works and what doesn't work, as well as learn from their classmates' comments. Although the students have most likely presented using PowerPoint several times during the educational experience, it might be the first time that their presentation skills, PowerPoint creation skills and financial skills are all required and graded simultaneously.

The students also must rate their group members' participation in the project. This enables the instructor to assign a lower score to the students that do not do their share of the work. This is particularly important in an online course since it sometimes for difficult for the instructor to monitor an individual student's participation in the group. The following form is filled out by each group member:

Figure 4: Group Member Evaluation Form

\begin{tabular}{|l|l|l|}
\hline \multicolumn{2}{|l|}{ Group Member Evaluation } \\
Your Name: \\
\hline \multicolumn{2}{|l|}{ Points 1-5 } \\
\hline Your Group \#: & & \\
\hline Presenter Name: & & \\
\hline Presenter Name: & & \\
\hline Presenter Name: & & \\
\hline Presenter Name: & & \\
\hline Presenter Name: & & \\
\hline
\end{tabular}

\section{LEARNING COMMUNITY}

A successful course is one that provides the students with the opportunity to learn. One key to the learning process is the ability for students to interact among themselves as well as with their instructor, and the collaboration in learning that results from the interactions (Palloff \& Pratt, 1999). An effectively designed course is one that provides students with the ability to use several different methods of interaction. The establishment of a learning community in class aids in the learning process. The idea is for the students to be placed into small groups based on similar goals, enabling them to be supportive of each other as they work towards their common academic goals (Harnett, Lucas, Miles, \& Sopper, 2004). Small group assignments and group discussions help promote the collaborative learning process (Palloff \& Pratt, 2001).

This course was designed to promote interaction in both the onground and online sections. The onground sections are taught as web-assisted courses. The majority of the lectures and interactions take place in the classroom. Discussion boards are created for the onground students to discuss individual assignments as well as their group project. The course tool enables them to use a mix of discussion boards, chat rooms and email for interacting. The online students have only the online interaction tools available to them; however, they often interact through phone calls as well. The students are encouraged to collaborate with one another on their individual assignments. They often provide their classmates with suggestions on the appropriate use of Excel for the assignments as well as share their real-world work experiences related to the assignments. By the end of the semester, many of the groups have been transformed into effective working virtual teams. This experience should help them in their future careers, especially as more and more global organizations operate with virtual teams. 


\section{OUTCOMES ASSESSMENT}

One final component of this course is outcomes assessment. This course is used to assess both the program competencies as well as the institutional competencies. The program outcomes assessment consists of two assessments. As mentioned previously, the students receive a program post-test assessment as part of their final exam. We also use one of their individual assignments as a program outcomes assessment measurement. A group of outside individuals grades the assignment based on rubrics developed by the finance department. The results are evaluated on an annual basis to determine if the program core competencies are being met. The institutional competencies include both research skill competencies and communication skills competencies. A group of outside individuals evaluate the student presentations, both the PowerPoint presentations and the written papers to determine if the institutional core competencies are being met.

\section{CONCLUSION}

This capstone course was designed to give the students several opportunities to work on the skills they will need in their careers. Most of the assignments require the students to apply the knowledge in real world applications, similar to what they may experience on the job. The course also helps them tie together knowledge acquired in courses outside the finance program. For example, the students all had one or more computer courses during their four years of education. In this course, they learn how to apply that knowledge specifically to the finance field. The research project was designed to enable the students to work on all of five of the core competencies necessary for success in the finance field: presentation skills, writing skills, team work skills, technology skills and analytical skills.

This course is also used as one of the main outcomes assessment measures for both accreditation purposes as well as continuous quality improvement in the program curriculum. The data will be monitored on an annual basis and program changes will be implemented as indicated by the data.

We have found this new required capstone course to be beneficial to the students and the faculty. Although some of the components of this course may change over the coming years, we plan to continue requiring this capstone course of all graduating BBA Finance students. Walsh has been successful in delivering this course both onground and online, and will continue to offer the course in both formats.

\section{AUTHOR INFORMATION}

Linda S. Wiechowski, Ph.D., earned a bachelor degree in accounting from Walsh College. She also holds a Masters in Business Administration and a PhD in Economics, both from Wayne State University. She has been teaching finance and economics courses at Walsh College for over 20 years. Her research interests include a variety of corporate finance topics, health economics, and the integration of online technology in all levels of education. She has presented "Best Practices in Online Education" at a variety of conferences.

\section{REFERENCES}

1. Chidambaram, L. \& Zigurs, I. (2001). Our virtual world: The transformation of work, plan and life via technology. Hershey, PA: Idea Group.

2. French, G. R. \& Coppage, R. E. (2004). Implementing curricula to meet the needs of financial professionals, Journal of College Teaching and Learning, 1 (10), 63-70.

3. Harnett, K., Lucas, S. R., Miles, B. E. \& Sopper, J. R. (2004). Learning communities: A business school perspective, Journal of College Teaching and Learning, 1 (3), 19-26.

4. Heinemann, R. L. (1997, November). The senior capstone, dome or spire? Paper presented at the Annual Meeting of the National Communication Association $83^{\text {rd }}$, Chicago, IL.

5. Katzenbach, J. R. \& Smith, D. K., (2004). The discipline of teams. In Harvard Business Review on Teams that Succeed (pp. 1-26). Boston, MA: Harvard Business School Publishing Corporation. 
6. Levine, A. (1998). A president's personal and historical perspective. In J. N. Gardner, G. Van der Veer and associates (Eds.), The senior year experience: Facilitating integration, reflection, closure, and transition (pp. 51-59). San Francisco, CA: Jossey-Bass Inc.

7. Marquardt, M. J. \& Kearsley, G. (1999). Technology-based learning: Maximizing human performance and corporate success. Boca Raton, FL: CRC Press LLC.

8. Palloff, R. M., \& Pratt, K. (1999). Building learning communities in cyberspace: Effective strategies for the online classroom. San Francisco, CA: Jossey-Bass Inc.

9. Palloff, R. M., \& Pratt, K. (2001). Lessons from the cyberspace classroom: The realities of online teaching. San Francisco, CA: John Wiley \& Sons, Inc.

10. Smith, B. L. (1998). Curricular structures for cumulative learning. In J. N. Gardner, G. Van der Veer and associates (Eds.), The senior year experience: Facilitating integration, reflection, closure, and transition (pp. 81-94) San Francisco, CA: Jossey-Bass Inc.

11. Walsh College. (2010). Course Descriptions. Retrieved August 10, 2010, from http://www.walshcollege.edu/upload/docs/Academics/CourseDesc2010-11.pdf. 
NOTES 